Article

\title{
Optimization of TiC Content during Fabrication and Mechanical Properties of Ni-Ti-Al/TiC Composites Using Mixture Designs
}

\author{
Dong-Jin Lee ${ }^{1}{ }^{(\mathbb{D}}$, Jae-Ha Park ${ }^{2}$ and Myung-Chang Kang ${ }^{1, *}$ \\ 1 Graduate School of Convergence Science, Pusan National University, Busan 46241, Korea; \\ eastjin218@naver.com \\ 2 Software Division South Office, IREATECT Co., Busan 49465, Korea; jhpark@minitab.co.kr \\ * Correspondence: kangmc@pusan.ac.kr; Tel.: +82-51-510-2361
}

Received: 13 May 2018; Accepted: 2 July 2018; Published: 4 July 2018

check for updates

\begin{abstract}
Ni-Ti-Al alloys are highly promising materials for use in high-temperature structural materials. However, minimal research has been conducted to improve the associated mechanical properties through secondary phase addition. In this study, $\mathrm{Ni}-\mathrm{Ti}-\mathrm{Al} / \mathrm{TiC}$ composites were fabricated at a pressure of $40 \mathrm{MPa}$ and a sintering temperature of $1050{ }^{\circ} \mathrm{C}$ using spark plasma sintering. The microstructure and interfacial structure were analyzed by scanning electron microscopy, energy dispersive $\mathrm{X}$-ray spectroscopy, and X-ray diffraction analysis. Microscopic analysis revealed that $\mathrm{TiC}$ particles interacted with $\mathrm{Ti}$ and $\mathrm{Al}$, resulting in the formation of $\mathrm{Ti}_{2} \mathrm{AlC}$, which promoted chemical metallurgical bonding between the $\mathrm{Ni}-\mathrm{Ti}-\mathrm{Al}$ alloy and $\mathrm{TiC}$. Wear characteristics were measured using the wear test with a ball on disk. It was confirmed that the $40 \mathrm{wt} \%$ specimen had the highest hardness due to pores generated inside, but the wear amount was relatively high. The mixture design of a minitap was proceeded using hardness, bending strength, and wear loss. An optimum composition ratio of $32.16 \mathrm{wt} \%$ was determined using the composite desirability of the three properties.
\end{abstract}

Keywords: Ni-Ti-Al/TiC; tribology behavior; spark plasma sintering; mixture designs; TiC content optimization

\section{Introduction}

The potential application of Ni-Ti-Al-based alloys for use in aerospace and high-temperature structural materials is acknowledged with respect to their low density, high strength at high temperatures, and high corrosion resistance. Initial studies improved the strength of Ni-Ti-based shape memory alloys at high temperatures by preparing Ni-Ti-Al by the substitution of a small amount of Ti with $\mathrm{Al}[1,2]$. Furthermore, a recent study was conducted to improve the corrosion resistance at high temperatures and prevent a deterioration in mechanical properties, in which less than 10 at $\% \mathrm{Al}$ was used for the precipitation of the $\mathrm{Ni}_{2} \mathrm{TiAl}$ phase and NiTi phase [3].

To improve the mechanical properties of Ni-Ti-Al-based alloys, metal elements, such as Mo, $\mathrm{Nb}$, Hf, Zr, B, and Re, have been added to alloys [4-6], and these properties have also been evaluated at room temperature. For example, the refractory alloy, Mo, was added at the interface between TiAl and $\mathrm{NiAl}$ to improve yield strength and compression strength, and $\mathrm{Nb}$ was added to improve the oxidation resistance. To improve the mechanical properties at high temperature, Ni-45Ti-5Al-2Nb-1Mo alloy was prepared by adding a small amount of at\% [7]. In addition, studies have been conducted to improve the compressive strength at room temperature by preparing ( $\mathrm{Ti}, \mathrm{Al}) 2 \mathrm{Ni}$ and $(\mathrm{Zr}, \mathrm{Ti}, \mathrm{Al}) 2 \mathrm{Ni}$ solid phase by adding 8 at\% of $\mathrm{Zr}$ [8], and numerous studies have investigated methods to improve high-temperature properties $[3,9,10]$. 
However, it is necessary to research the application of metal- or ceramics-based composites in extreme environments due to the development of advanced industries. Mechanical properties research has previously been limited to compressive strength tests (because these composites are high-temperature structural materials), but limited research has used room temperature to investigate the wear loss of the product or evaluate its mechanical properties. Furthermore, mechanical properties have been evaluated under limited conditions, due to the uniform composition ratio of the added materials; however, few studies have aimed to find the optimal composition ratio because composition ratio tests are expensive and time-consuming.

Therefore, in this study, $\mathrm{TiC}[11,12]$ with various composition ratios is added to $\mathrm{Ni}-\mathrm{Ti}-\mathrm{Al}$ and sintered using identical sintering conditions in all experiments. The material properties are analyzed by measuring the microstructure, composition distribution, phase, and density; and mechanical properties, such as bending strength, hardness, and wear loss are measured and applied to the mixture design. The optimum content of $\mathrm{TiC}$ is obtained using the composite desirability of the mixture design.

\section{Materials and Methods}

In this experiment, $\mathrm{Ti}(99.96 \%, 45 \mu \mathrm{m}), \mathrm{Al}(99.95 \%, 45 \mu \mathrm{m}), \mathrm{Ni}(99.9,45 \mu \mathrm{m})$, and $\mathrm{TiC}(99.95 \%$, $3 \mu \mathrm{m}$ ) were employed at the composite ratios shown in Table 1 . In the chemical reaction presented in Equation (1), all of the TiC can disappear during sintering, so that the conditions were excepted the composition of TiC $10 \mathrm{wt} \%$. SUS balls with diameters of $10 \mathrm{~mm}$ were mixed at a ball/powder ratio (BPR) of 10:1 for $10 \mathrm{~h}$.

$$
\mathrm{Ti}+\mathrm{Al}+\mathrm{TiC} \rightarrow \mathrm{Ti}_{2} \mathrm{AlC}
$$

Table 1. Chemical composition of mixed powders (wt \%).

\begin{tabular}{ccccc}
\hline Sample & Ni & Ti & Al & TiC \\
\hline Ni-Ti-Al/20 wt \% TiC & 40 & 36.8 & 3.2 & 20 \\
Ni-Ti-Al/30 wt \% TiC & 35 & 32.2 & 2.8 & 30 \\
Ni-Ti-Al/40 wt \% TiC & 30 & 27.6 & 2.4 & 40 \\
\hline
\end{tabular}

The Ni-Ti-Al/TiC powders were charged into a graphite mold with a diameter of $30 \mathrm{~mm}$, pre-formed by hand press, and then sintering using spark plasma sintering (SPS: DR. SINTER SPS-825, FUJI-SPS, Gothenburg, Japan). In the preliminary experiment, the sintered material exited from the graphite mold at a pressure of $40 \mathrm{MPa}$ and at temperatures of $1100{ }^{\circ} \mathrm{C}$ or higher and adhered to the disk. Therefore, sintering was subsequently conducted by maintaining the pressure at $40 \mathrm{MPa}$, the temperature elevation at $100{ }^{\circ} \mathrm{C} / \mathrm{min}$, and the sintering temperature of $1050{ }^{\circ} \mathrm{C}$ for $10 \mathrm{~min}$ in a vacuum atmosphere. The densities of the specimens were measured using the Archimedes method, and the average of five measured values was used to calculate the theoretical density. Relative density values were calculated using Equation (2) to determine the porosity of specimens,

$$
K=\frac{\rho}{\rho_{0}} \times 100 \%,
$$

where $K$ is the relative density, $\rho$ is measured density, and $\rho_{0}$ is theoretical density. $X$-ray diffraction (XRD: D8-ADVANCE, Bruker, MA, USA) was used to analyze the phase as the content of TiC increased. The wear amount of the specimen was measured by a ball-on-a-disk-type wear tester (High temperature wear tester, R\&BCo. Ltd., Daejeon, Korea); the microstructure and indentation of the wear specimen were measured using scanning electron microscopy (SEM, S-4800, HITACHI, Chiyoda, Japan) and energy dispersive X-ray spectroscopy (EDS: EDAX, Bruker, MA, USA); hardness was measured using a Vickers hardness tester (VMT-X7, Matsuzawa, Akita, Japan); and bending strength was measured using the indentation fracture method at a load of $5 \mathrm{~N}$. Test specimens were prepared in $4 \mathrm{~mm} \times 8 \mathrm{~mm} \times 24 \mathrm{~mm}$ according to the KS D ISO 3325 standard [13] using a discharge wire. 
They were then measured three times, and the bending strength was expressed using the average, maximum, and minimum range.

The mixture design was processed in Minitab 17 (Minitab Inc., State College, PA, USA) using the measured bending strength, hardness, and wear loss. The vertex design represents the mixture design when the composition ratio is limited to the maximum and minimum, and Figure 1 shows a composite rate schematic diagram of the $\mathrm{Ni}-\mathrm{Ti}-\mathrm{Al} / \mathrm{TiC}$ composite vertex design at ratios of 80:20, 60:40 wt \% (angle point), and 70:30 wt \% (middle point). As the design utilizes two deviations and variances, it was performed twice for each condition. The middle point was added to confirm the tendency between the two points and proceeded six times in total. The degree of similarity between the model and actual data were analyzed using the measured values of hardness, bending strength, and wear loss. The maximum $\left(\mathrm{d}_{\mathrm{M}}\right)$ was selected by setting the minimum value $\left(\mathrm{L}_{\mathrm{i}}\right)$ and target value $\left(T_{i}\right)$ of hardness and bending strength, and the minimum $\left(\mathrm{d}_{m}\right)$ was selected by setting the maximum value $\left(\mathrm{H}_{\mathrm{i}}\right)$, and target value of wear loss. The composite desirability is expressed as a combination of the maximum $\mathrm{d}$ or minimum $\mathrm{d}$ of individual desirability $(\mathrm{d})$. The desirability function weight $\left(\mathrm{r}_{\mathrm{i}}\right)$ was calculated for individual desirability (d) and composite desirability when emphasizing the importance of each expected response value $\left(\mathrm{y}_{\mathrm{i}}\right)$, and the function is shown in Figure 2. A range between 0.1 and 10 is possible; if the value is larger than 1 then the reaction value is closer to the target value, whereas if it is lower than 1 then the optimum condition is found (even if the reaction value does not move close to the target value).

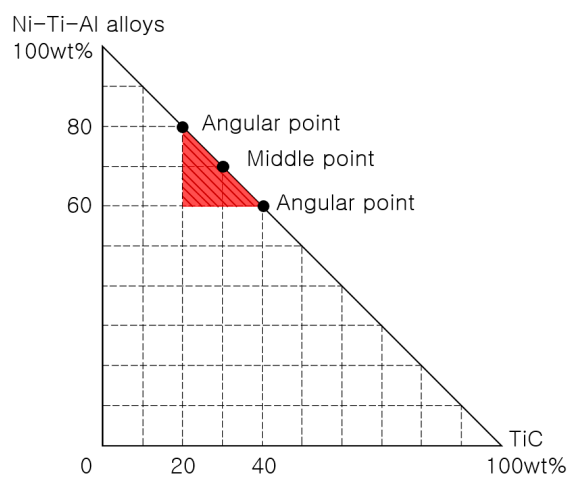

Figure 1. Schematic diagram of $\mathrm{Ni}-\mathrm{Ti}-\mathrm{Al} / \mathrm{TiC}$ composite ratios in mixture design using Minitab 17.

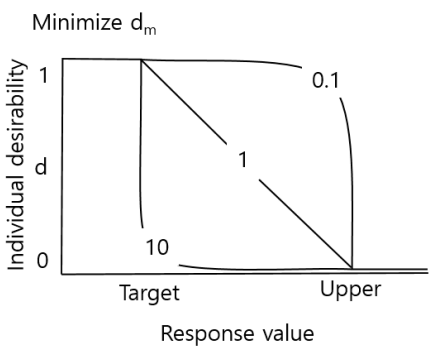

(a)

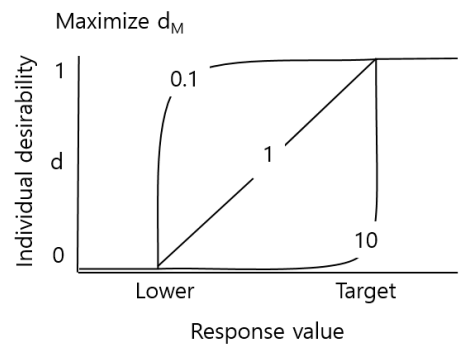

(b)

Figure 2. Principle schematic diagram of applying weight of desirability function in mixture design.

(a) Minimize $\mathrm{d}_{\mathrm{m}}$; (b) Maximize $\mathrm{d}_{\mathrm{M}}$.

\section{Results and Discussion}

\subsection{Optimization of TiC Contents through the Mixture Design}

The reaction optimization tool can identify a single response or a combination of input variables and provide optimization of individual desirability and composite desirability. Individual desirability (d) is calculated in the range from 0 to 1 (where 1 is ideal and maximum $\left(\mathrm{d}_{\mathrm{M}}\right)$ and minimum $\left(\mathrm{d}_{\mathrm{m}}\right)$ 
values are calculated based on formula (3). $\mathrm{d}$ is the distance $\mathrm{d}$ between maximum value $\left(\mathrm{H}_{\mathrm{i}}\right)$, minimum value $\left(\mathrm{L}_{\mathrm{i}}\right)$, the target value $\left(\mathrm{T}_{\mathrm{i}}\right)$ and the expected response value $\left(\mathrm{y}_{\mathrm{i}}\right)$. The composite desirability (D) is calculated in the range from 0 to 1 using Equation (4), by summing each response satisfaction, $d$, shown in Equation (3),

$$
\begin{gathered}
\operatorname{maximize} d_{M}=\left(\frac{\left(y_{i}-L_{i}\right)}{\left(T_{i}-L_{i}\right)}\right)^{r_{i}}, \text { minimize } d_{m}=\left(\frac{\left(H_{i}-y_{i}\right)}{\left(H_{i}-T_{i}\right)}\right)^{r_{i}}, \\
\text { composite desirability } D=\left(d^{r_{1}}{ }_{1} \times d^{r_{2}}{ }_{2} \times \ldots \times d_{n}\right)^{1 / W},
\end{gathered}
$$

where $r_{i}$ is the weight of the desirability function of the ith response; and $W$ is $\Sigma r_{i}$.

Figure 3 shows the optimization of the composition using the reaction optimization tool. This experiment was conducted by choosing the same weight as 1 to determine the characteristics of mechanical properties, but not with respect to their commercialization. The optimum composition was selected as 0.5873 (Ni-Ti-Al: $67.84 \mathrm{wt} \%$, TiC: $32.16 \mathrm{wt} \%$ ). However, individual satisfaction with respect to bending strength was low because of the large difference between the target and minimum values. Nevertheless, this composition was selected because of the slight increase in individual satisfaction with respect to wear loss and hardness compared to the increase in individual satisfaction with respect to bending strength. This experiment was used to confirm the feasibility of characterization and optimization according to the composition of $\mathrm{TiC}$, and it is acknowledged that the optimal composition ratio may vary depending on the weight. In Figure $3 b$, the bending-strength weight of the desirability function is selected as 5 .

a) All of response value weight of desirability is 1

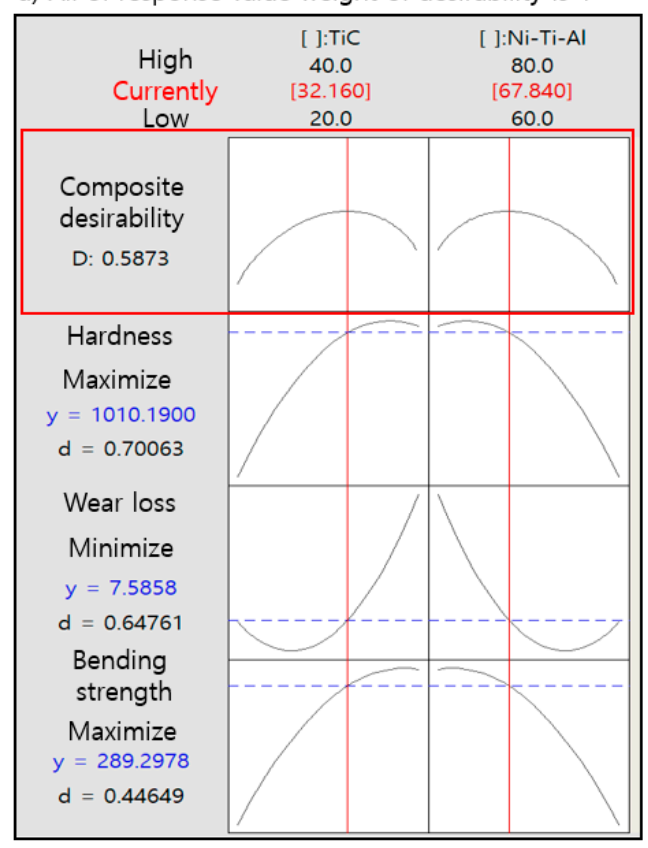

b) Bending strength weight of desirability is 5

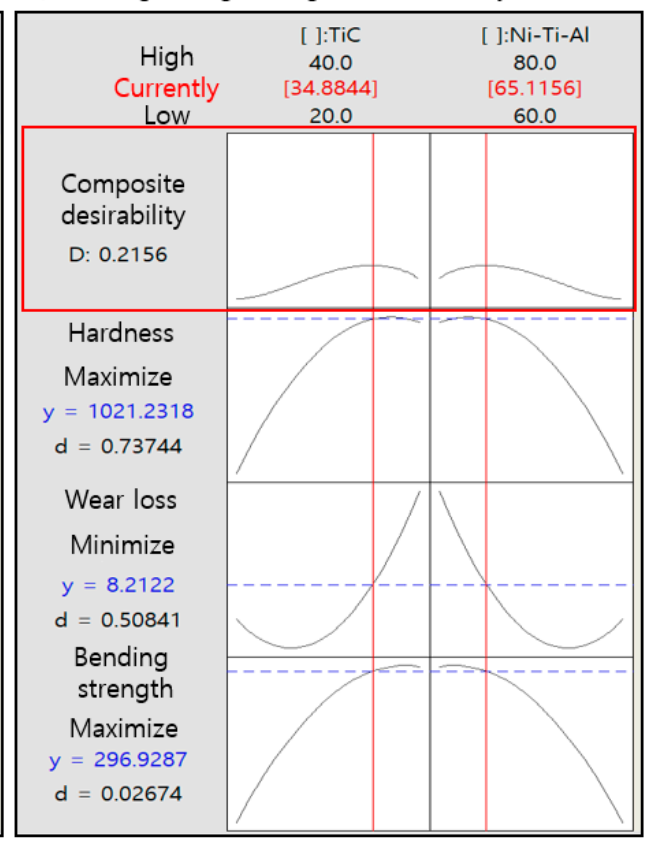

Figure 3. Response optimizer for mixture design using Minitab 17. (a) All of response value weight of desirability is 1 ; (b) Bending strength weigh of desirability is 5 .

\subsection{Effect of TiC Contents on Density and XRD Pattern Microstructure of Ni-Ti-Al/TiC Composites}

Table 2 shows the theoretical, measured, and relative densities of the $\mathrm{Ni}$-Ti-Al/TiC composites. As the $\mathrm{TiC}$ content increased, the theoretical and measured density values decreased with respect to the decrease in the composition ratio of $\mathrm{Ni}$, which has a relatively high density. In addition, sintering under the same sintering conditions shows that the relative density decreased under the condition 
of $40 \mathrm{wt} \% \mathrm{TiC}$. This is attributed to an insufficient penetration of the low contact angle of Ni-Ti-Al between the particles of $\mathrm{TiC}$, and the formation of pores during sintering due to the increase in $\mathrm{TiC}$.

Table 2. Density of Ni-Ti-Al/TiC composition.

\begin{tabular}{|c|c|c|c|}
\hline Sample & $\begin{array}{l}\text { Theoretical Density } \\
\qquad\left(\mathrm{g} / \mathrm{cm}^{3}\right)\end{array}$ & $\begin{array}{l}\text { Measured Density } \\
\left(\mathrm{g} / \mathrm{cm}^{3}\right)\end{array}$ & $\begin{array}{l}\text { Relative Density } \\
\qquad\left(\mathrm{g} / \mathrm{cm}^{3}\right)\end{array}$ \\
\hline $\mathrm{Ni}-\mathrm{Ti}-\mathrm{Al} / 20$ wt $\% \mathrm{TiC}$ & 5.59 & 5.52 & $98.8 \%$ \\
\hline $\mathrm{Ni}-\mathrm{Ti}-\mathrm{Al} / 30$ wt $\% \mathrm{TiC}$ & 5.50 & 5.41 & $98.4 \%$ \\
\hline $\mathrm{Ni}-\mathrm{Ti}-\mathrm{Al} / 40$ wt $\% \mathrm{TiC}$ & 5.41 & 5.25 & $97.1 \%$ \\
\hline $\mathrm{Ni}-\mathrm{Ti}-\mathrm{Al} / 32.16$ wt $\% \mathrm{TiC}$ & 5.48 & 5.37 & $98.1 \%$ \\
\hline
\end{tabular}

Figure 4 shows the phase composition of the mixes and sintered composites. The main phases found in the mixes are $\mathrm{Ni}, \mathrm{Ti}, \mathrm{Al}$, and $\mathrm{TiC}$, and phases found in the sintered composites are $\mathrm{NiTi}, \mathrm{Ti}_{2} \mathrm{Ni}$, $\mathrm{TiC}, \mathrm{Ni}_{3} \mathrm{Ti}, \mathrm{TiAl}, \mathrm{Ti}_{2} \mathrm{AlC}$ complex phases and $\mathrm{Ti}, \mathrm{Ni}, \mathrm{Al}$ phases. As the content of $\mathrm{TiC}$ increased under the same sintering condition, the peak of TiC increased in the range of $20 \mathrm{wt} \%$ to $40 \mathrm{wt} \%$ but the $\mathrm{Ti}_{2} \mathrm{AlC}$ peak decreased at $40 \mathrm{wt} \%$. It is assumed that the $\mathrm{TiC}$ powder was incompletely sintered at the interface of $\mathrm{Ni}-\mathrm{Ti}-\mathrm{Al}$ and $\mathrm{TiC}$ in these reactions [12]. XRD showed that at $\mathrm{TiC}$ peak values of $20 \mathrm{wt} \%$ and $30 \mathrm{wt} \%, \mathrm{TiC}$ was synthesized to $\mathrm{Ti}_{2} \mathrm{AlC}$. In addition, with increased amounts of $\mathrm{TiC}$, values of $\mathrm{Ni}_{3} \mathrm{Ti}$ and NiTi decreased and the Ni peak rose due to the decreased $\mathrm{Ni}$ reaction.

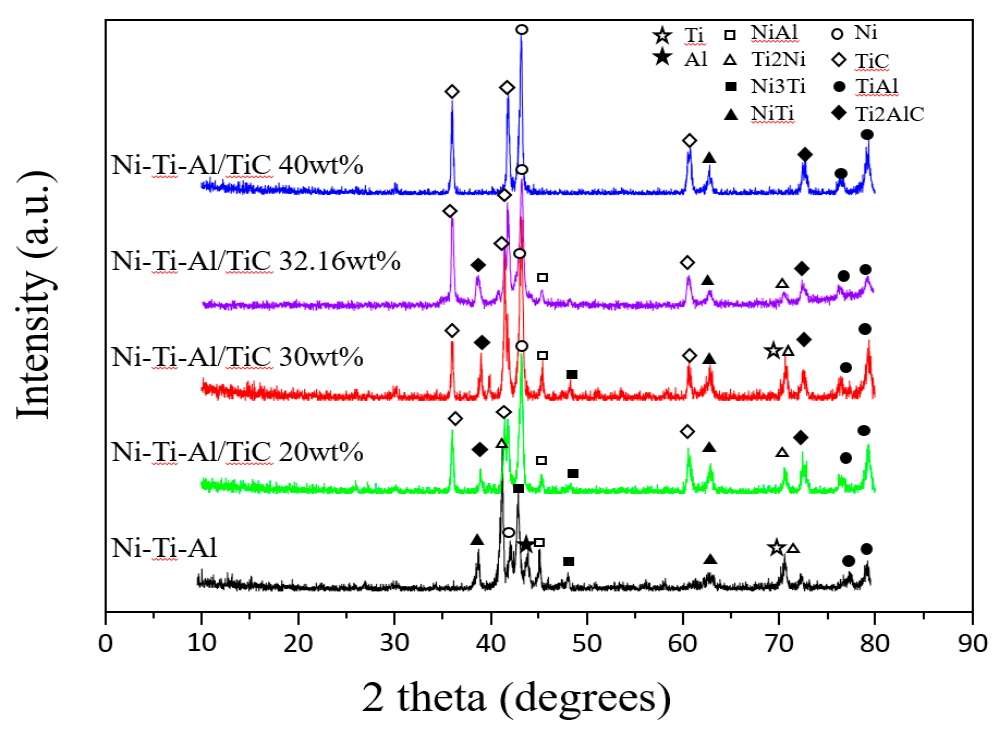

Figure 4. XRD analyses of Ni-Ti-Al/TiC composition and Ni-Ti-Al alloy.

Figure 5 shows the microstructure of the fabricated $\mathrm{Ni}-\mathrm{Ti}-\mathrm{Al} / \mathrm{TiC}$ composites with $\mathrm{TiC}$ contents of $20,30,32.16$, and $40 \mathrm{wt} \%$. The TiC particle was uniformly distributed in the Ni-Ti-Al alloy matrix at TiC contents of 20 and $30 \mathrm{wt} \%$. The number of fine-sized $(3-5 \mu \mathrm{m}) \mathrm{TiC}$ particles increased abruptly at $32.16 \mathrm{wt} \%$ and $40 \mathrm{wt} \%$. However, TiC and Ni-Ti-Al were not uniformly distributed at $40 \mathrm{wt} \%$ and were found to be united. Table 2 and Figure 5 show that Ni-Ti-Al did not penetrate sufficiently between the $\mathrm{TiC}$ particles as the content increased, resulting in pores in the interface of $\mathrm{TiC}$ and $\mathrm{Ni}$-Ti-Al.

Figure 6 shows the microstructure and distribution of elements across the interface between the $\mathrm{TiC}$ and the Ni-Ti-C alloy, as determined by EDS. EDS mapping analyses revealed a distribution gradient for the elemental composition: Ti was distributed as a whole, and $\mathrm{Ni}, \mathrm{Al}$, and $\mathrm{C}$ were partially concentrated. The distributions and phases of TiC and Ni-Ti-Al alloys were confirmed and are shown in Figures 4 and 6. The formation of Ti2AlC was observed using the compositional distribution at the interfacial bonding between the $\mathrm{Ni}-\mathrm{Ti}-\mathrm{Al}$ and $\mathrm{TiC}$. Results showed an almost complete lack of $\mathrm{Ni}$ in the 
interface between $\mathrm{Ni}-\mathrm{Ti}-\mathrm{Al}$ and $\mathrm{TiC}$ but a region where $\mathrm{Al}$ and $\mathrm{C}$ were common, which is considered to be a Ti2AlC layer with a 0.5 to $1 \mu \mathrm{m}$ interval. Figure 7 shows a line scan analysis using EDS. Due to the nature of high-energy sintering equipment, SPS, the components are seen to be diffused and were measured as a whole, but it was possible to obtain high peaks at key locations. The decrease in the Ni peak in the interface region of $\mathrm{Ni}-\mathrm{Ti}-\mathrm{Al}$ and $\mathrm{TiC}$ was larger than the decrease in the $\mathrm{Al}$ peak. In addition, the gray section was confirmed to be a Ti2AlC layer of $0.5 \mu \mathrm{m}$, due to the distribution peak of C.

$$
\begin{gathered}
3 \mathrm{Ni}+\mathrm{Ti} \rightarrow \mathrm{Ni}_{3} \mathrm{Ti}, \\
3 \mathrm{Ti}+2 \mathrm{Al}+2 \mathrm{Ni} \rightarrow \mathrm{TiAl}, \mathrm{NiAl}, \mathrm{Ti}_{2} \mathrm{Ni},
\end{gathered}
$$
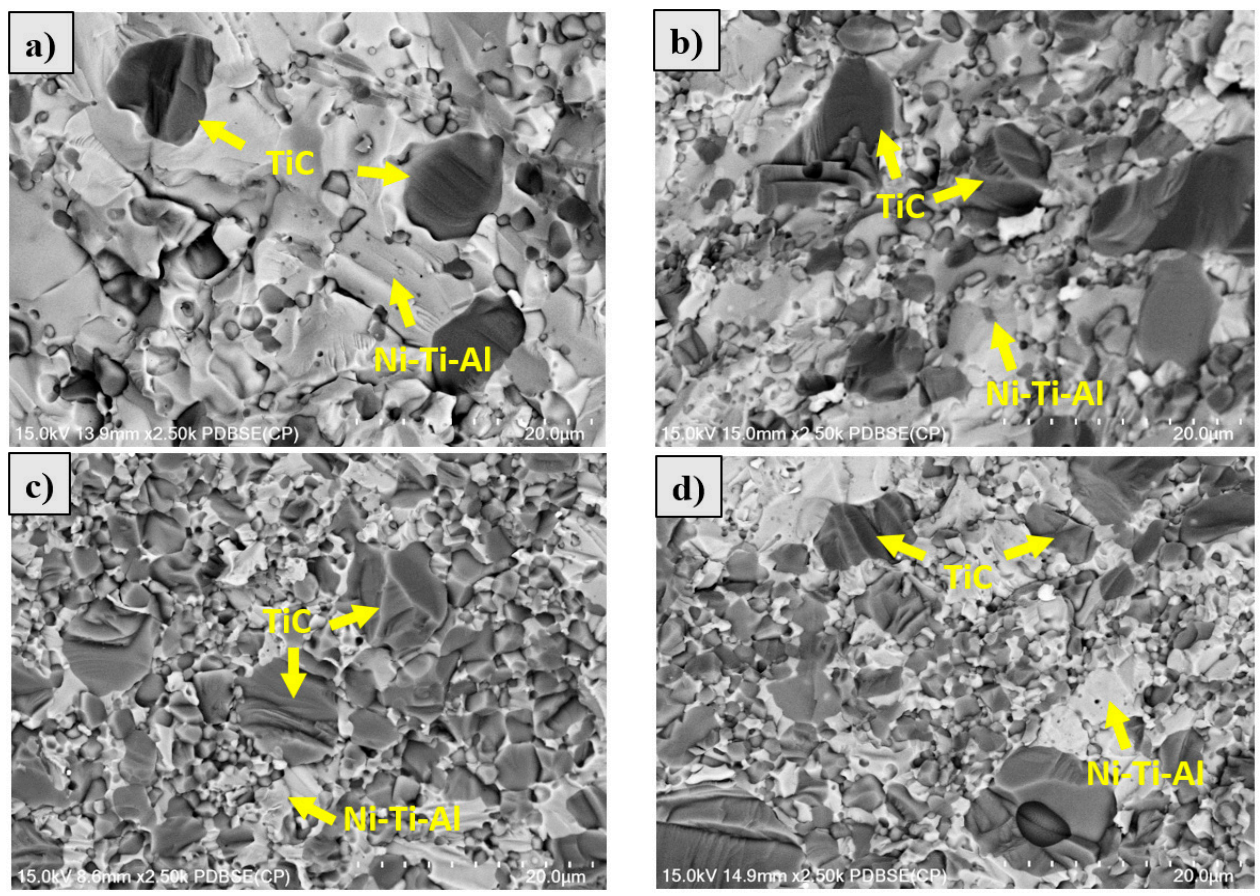

Figure 5. Microstructure of $\mathrm{Ni}-\mathrm{Ti}-\mathrm{Al} / \mathrm{TiC}$ composites by SPS BSE of: (a) TiC content 20 wt \%; (b) TiC content $30 \mathrm{wt} \%$; (c) TiC content $32.16 \mathrm{wt} \%$; (d) TiC content $40 \mathrm{wt} \%$.
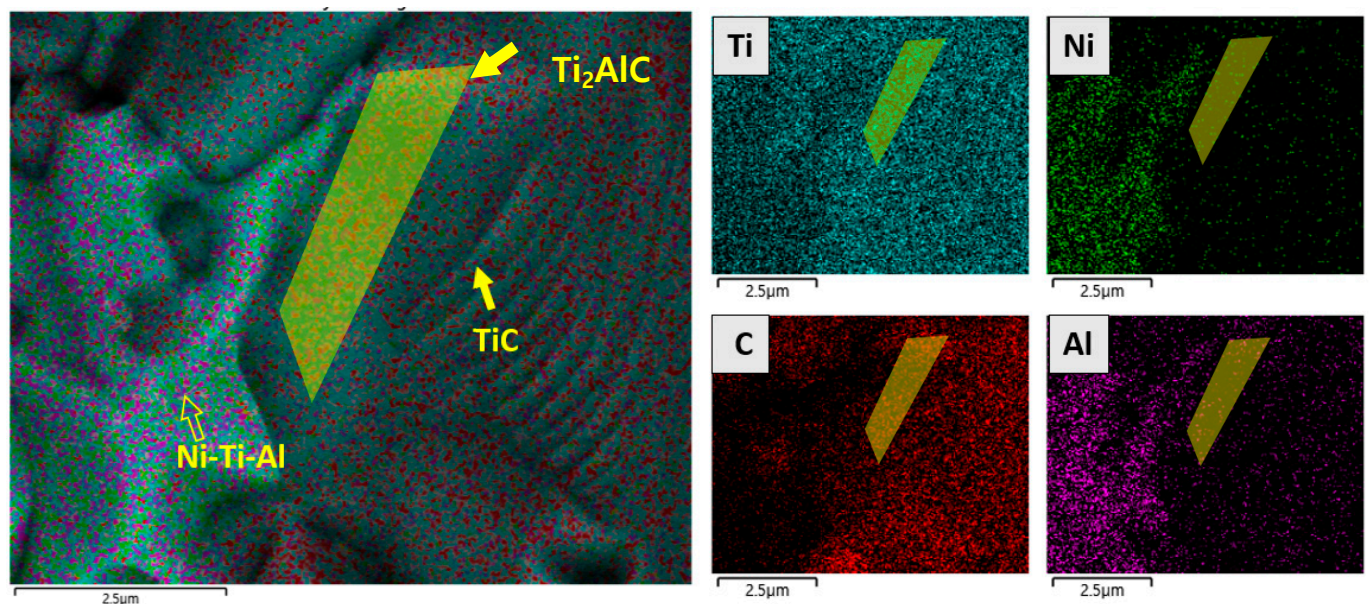

Figure 6. SEM images and EDS elemental mapping analysis of Ni-Ti-Al/TiC composites. 

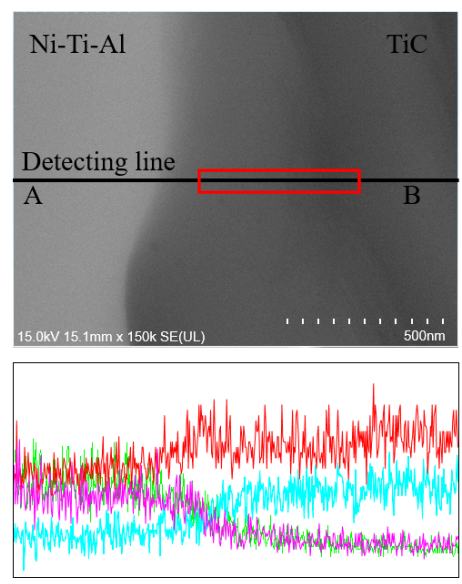

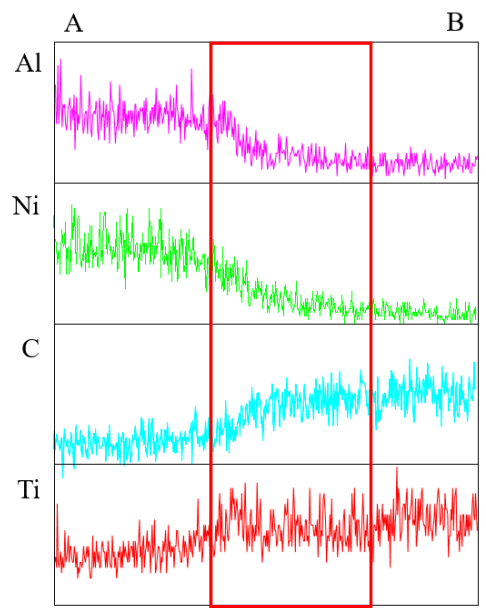

Figure 7. Microstructure and EDS analysis of interface between TiC and Ni-Ti-Al alloy.

\subsection{Mechanical Properties of Ni-Ti-Al/TiC Composites}

Figure 8a shows a graph of changes in hardness with increases in the TiC composition. Hardness measured using a Vickers hardness meter was $8.3 \mathrm{GPa}$ at $20 \mathrm{wt} \% \mathrm{TiC}$, but it increased to 9.75 at $30 \mathrm{wt} \%$, and a further slight increase was detected at $40 \mathrm{wt} \%$ (from $9.75 \mathrm{GPa}$ to $9.98 \mathrm{GPa}$ ). Figures 2 and 3 show that the TiC distribution was higher on the surface, and higher hardness was maintained with a content of $40 \mathrm{wt} \%$ due to the higher distribution of TiC on the surface; however the Ni-Ti-Al alloy was not infiltrated into the TiC particle and the surface was therefore easily broken due to the occurrence of the pores and an inactive interface.
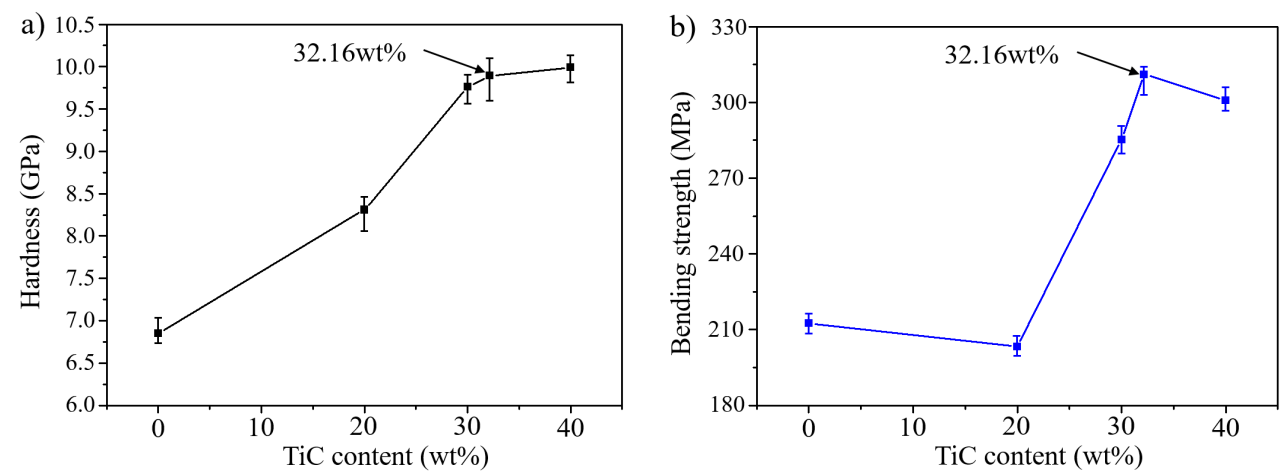

Figure 8. Effect of TiC contents on: (a) macro hardness and (b) bending stress.

Figure $8 \mathrm{~b}$ shows the bending strength according to the composition ratio, and it is evident that the value of the bending strength increases with an increasing $\mathrm{TiC}$ content. However, the strength at $\mathrm{TiC} 20 \mathrm{wt} \%$ is lower than that of the conventional Ni-Ti-Al alloy. The bending strength was increased in relation to the formation of $\mathrm{Ti}_{2} \mathrm{AlC}$, and the formation of the NiTi phase was inhibited with an increase in the number of $\mathrm{TiC}$ particles. This reason was presumed bending strength of the base metal and $30 \mathrm{wt} \%$. The interfacial bonding energy increased for the $\mathrm{TiC}$ and $\mathrm{Ni}$-Ti-Al alloy during the $\mathrm{Ti}_{2} \mathrm{AlC}$ phase. Figure 2 shows that when the content of TiC increased, formation of the NiTi phase was inhibited, and $\mathrm{Ti}_{2} \mathrm{AlC}$ was produced. However, the bending strength at $20 \mathrm{wt} \%$ and the bending strength of the base metal overlapped in the maximum superficial value range, which suggests that the formation of NiTi was suppressed but the formation of $\mathrm{Ti}_{2} \mathrm{AlC}$ was not smooth. The bending strength increased with an increase in the TiC content: the highest bending strength was $311 \mathrm{MPa}$ at the optimization composite ratio of $32.16 \mathrm{wt} \%$. However, although the hardness value is high, the bending strength decreased due to cracks relating to internal pores [14]. 
Figure 9 shows the amount of wear at each TiC composition ratio according to a change in load in the ball-on-disk type abrasion test: the amount of wear increased with an increase in the load. The amount of abrasion was lowest at a TiC content of $30 \mathrm{wt} \%$ and highest at $40 \mathrm{wt} \%$. There was a decrease in the abrasion amount at $30 \mathrm{wt} \%$ compared to $20 \mathrm{wt} \%$ due to the increase in hardness and bending strength. Although the TiC specimen at $40 \mathrm{wt} \%$ had a high density due to use of the high plasma density sintering method, the Ni-Ti-Al base material could not sufficiently bond with the $\mathrm{TiC}$. Therefore, the abrasion rate also increased rapidly when the $\mathrm{TiC}$ particles dropped out after the load increased $[14,15]$. In addition, the optimum condition of $32.16 \mathrm{wt} \%$ caused more abrasion than at $30 \mathrm{wt} \%$, but the difference was only slight.

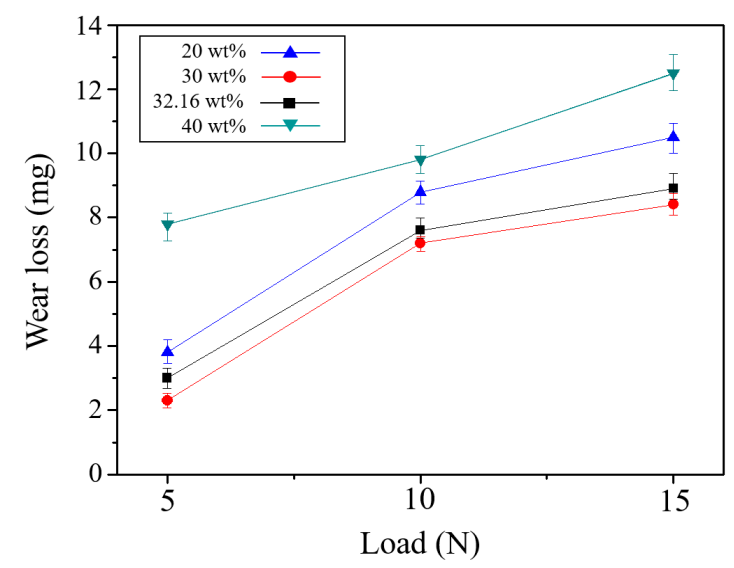

Figure 9. Effect of TiC content on wear loss according to load various.

Figure 10 shows photographs of the surfaces of wear test specimens. The cracks and traces of the wear tracks are more highly evident at $20 \mathrm{wt} \%$ and $40 \mathrm{wt} \%$ than at $30 \mathrm{wt} \%$, and craters are evident at $40 \mathrm{wt} \%$. It was confirmed that the unsintered TiC particles were separated from each other and that secondary wear had occurred. In addition, the result of EDS shown in Figure 10e evidences the reduction in areas of abrasion at $30 \mathrm{wt} \%$, which relates to the high TiC composition $[15,16]$.
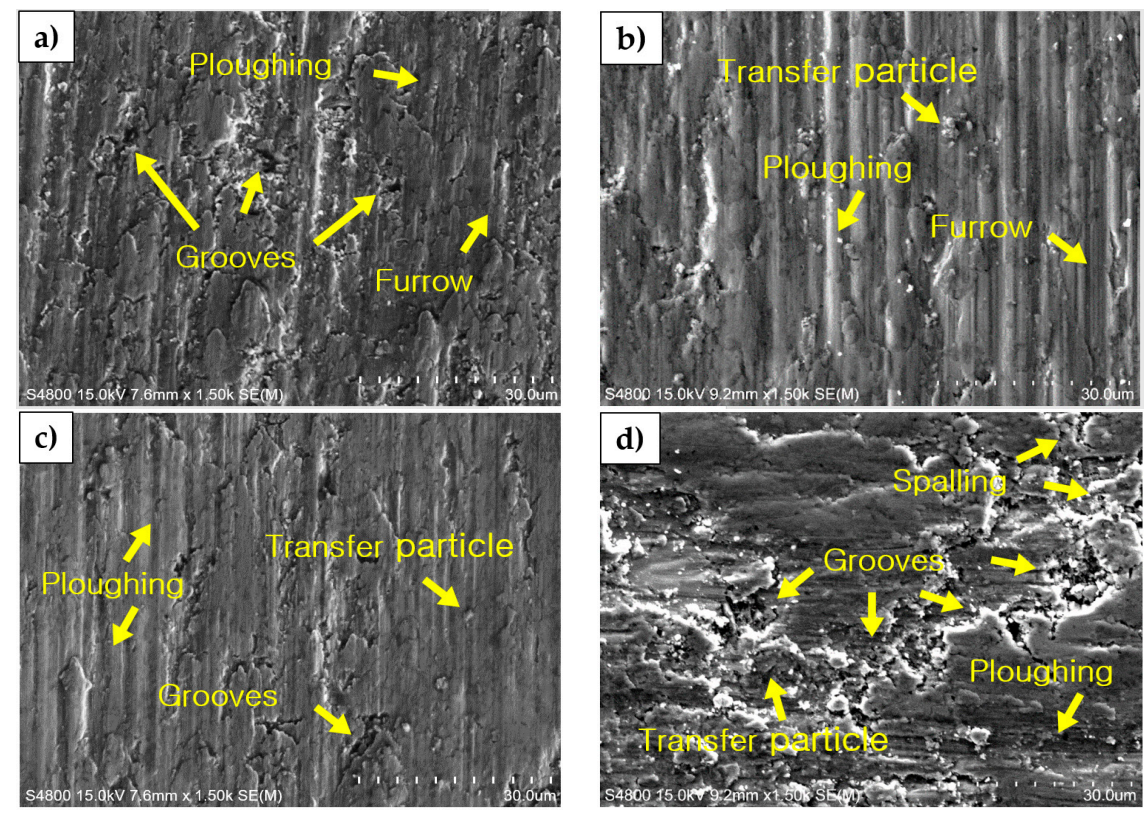

Figure 10. Cont. 


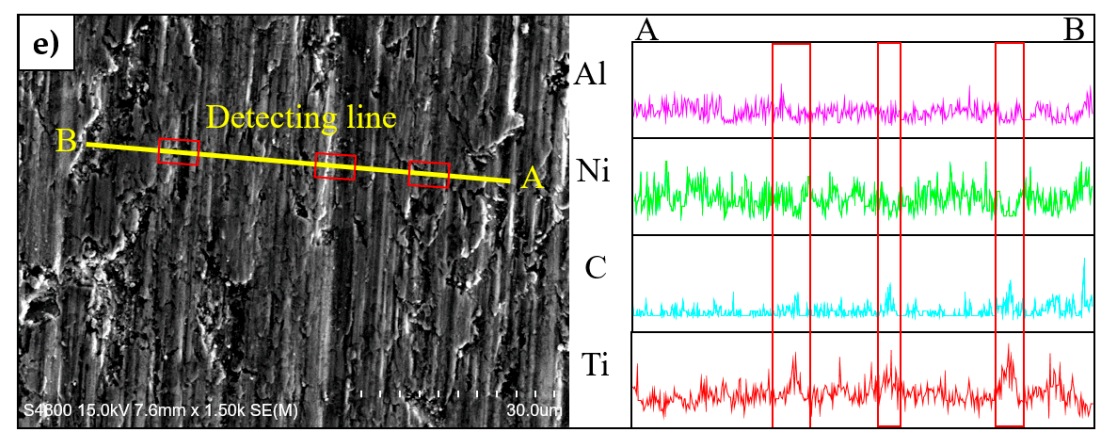

Figure 10. Abrasion surface of $\mathrm{Ni}-\mathrm{Ti}-\mathrm{Al} / \mathrm{TiC}$ composites by SPS SEM image of (a) TiC content of 20 wt \%; (b) TiC content of $30 \mathrm{wt} \%$; (c) TiC content of 32.16 wt \%; (d) TiC content of $40 \mathrm{wt} \%$; and EDS analysis showing (e) $\mathrm{TiC}$ content of $30 \mathrm{wt} \%$.

\section{Conclusions}

$\mathrm{TiC}$ was added to an Ni-Ti-Al alloy, which is a high-temperature structural material, and hardness, bending strength, and wear loss were measured at room temperature. The optimum condition was determined using the mixture synthesis method. The optimum composition ratio is considered to be a factor that can be used to improve the durability life of the product. The composition using the highest composite desirability was selected for all three compositions with high individual desirabilities, which thus suggests the possibility of optimization.

1. The $\mathrm{Ti}_{2} \mathrm{AlC}$ phase was increased with the addition of $\mathrm{TiC}$, but the $\mathrm{Ti}_{2} \mathrm{AlC}$ phase was not formed sufficiently between the interfaces due to the failure of TiC particles to penetrate smoothly at $40 \mathrm{wt} \%$. High densification was achieved using the spark plasma sintering method. However, density was reduced with an increase in the TiC content, and pores were generated at interfaces between TiC and Ni-Ti-Al.

2. The hardness value increased with an increase in the TiC content, and the highest hardness value was measured at $40 \mathrm{wt} \%$. In addition, $\mathrm{TiC}$ was saturated on the surface at $40 \mathrm{wt} \%$ and an increase range of hardness was decreased from $9.75 \mathrm{GPa}$ to $9.98 \mathrm{GPa}$.

3. The bending strength was increased due to the formation of $\mathrm{Ti}_{2} \mathrm{AlC}$, and the formation of the NiTi phase was inhibited with an increase in the TiC particles. The interfacing bonding energy increased between the $\mathrm{TiC}$ and $\mathrm{Ni}-\mathrm{Ti}-\mathrm{Al}$ alloy during the $\mathrm{Ti}_{2} \mathrm{AlC}$ phase. The $\mathrm{Ti}_{2} \mathrm{AlC}$ peak at $32.16 \mathrm{wt} \%$ was superior to that of the other content materials and the bending strength was superior at $311 \mathrm{MPa}$.

4. The TiC content has a significant effect on the wear resistance of the composites. At a TiC content of $30 \mathrm{wt} \%$, the weight loss of the composites reached a minimum value of $2.2 \mathrm{mg}$. Secondary wear occurred with the $\mathrm{TiC}$ particle by spalling at $\mathrm{TiC} 40 \mathrm{wt} \%$.

Author Contributions: D.-J.L. did the experiments, data analysis and wrote part of paper, J.-H.P. did data analysis and proofread the paper; M.-C.K. provided the original ideas.

Funding: This work was supported by a 2-Year Research Grant (201705660002) of Pusan National University.

Acknowledgments: The first and the second authors contributed equally to this work.

Conflicts of Interest: The authors declare no conflict of interest.

\section{References}

1. Koizumi, Y.; Ro, Y.; Nakazawa, S.; Harada, H. NiTi-base intermetallic alloys strengthened by Al substitution. Mater. Sci. Eng. A 1997, 223, 36-41. [CrossRef]

2. Meng, L.; Li, Y.; Zhao, $\mathrm{X}$; $\mathrm{Xu}, \mathrm{J}$.; $\mathrm{Xu}, \mathrm{H}$. The mechanical properties of intermetallic $\mathrm{Ni}_{50-\mathrm{x}} \mathrm{Ti}_{50} \mathrm{Al}_{\mathrm{x}}$ alloys $(\mathrm{x}=$ 6, 7, 8, 9). Intermetallics 2007, 15, 814-818. [CrossRef] 
3. Zhou, L.; Zheng, L.J.; Zhang, H. Effect of heating temperature on microstructure of directionally solidified Ni-43 Ti-7 Al alloy. Mater. Sci. Forum 2017, 898, 552-560. [CrossRef]

4. Song, X.; Li, Y.; Zhang, F. Microstructure and tensile properties of isothermally forged $\mathrm{Ni}-{ }_{43} \mathrm{Ti}_{-}{ }_{4} \mathrm{Al}-{ }_{2} \mathrm{Nb}-{ }_{2} \mathrm{Hf}$ alloy. Rare Met. 2013, 32, 475-479. [CrossRef]

5. Song, X.; Li, Y.; Zhang, F. Microstructure and mechanical properties of Nb- and Mo-modified NiTi-Al-based intermetallics processed by isothermal forging. Mater. Sci. Eng. A 2014, 594, 229-234. [CrossRef]

6. Song, X.; Li, Y.; Zhang, F.; Li, S. NiTiAl intermetallic alloys strengthened by Mo replacement. Chin. J. Aeronaut. 2010, 23, 715-719.

7. Li, Y.; Yu, K.; Song, X.; Zhang, F. Effect of Zr addition on microstructures and mechanical properties of $\mathrm{Ni}-{ }_{46} \mathrm{Ti}_{4} \mathrm{Al}$ alloy. Rare Met. 2011, 30, 522-526. [CrossRef]

8. Xu, H.; Meng, L.; Xu, J.; Li, Y.; Zhao, X. Mechanical properties and oxidation characteristics of TiNiAl (Nb) intermetallics. Intermetallics 2007, 15, 778-782. [CrossRef]

9. Xiaoyun, S.; Wenjun, Y.; Songxiao, H.; Yan, L. Oxidation behavior of NiTi-Al based alloy with $\mathrm{Nb}$ and $\mathrm{Mo}$ additions. IOP Conf. Ser. Mater. Sci. Eng. 2017, 250,1-5. [CrossRef]

10. Zheng, Y.; Zhou, Y.; Li, R.F.; Wang, J.Q.; Chen, L.L.; Li, S.B. Preparation and mechanical properties of TiC-Fe cermets and TiC-Fe/Fe bilayer composites. J. Mater. Eng. Perform. 2017, 26, 4933-4939. [CrossRef]

11. Wang, Z.; Lin, T.; He, X.B.; Shao, H.P.; Tang, B.; Qu, X.H. Fabrication and properties of the TiC reinforced high-strength steel matrix composite. Int. J. Refract. Met. Hard Mater. 2016, 58, 14-21. [CrossRef]

12. Liu, N.; Chen, M.H.; Xu, Y.D.; Zhou, J.; Shi, M. Wettability and bonding between Ni and Ti(C, N) with multiple carbide additions. J. Mater. Sci. Technol. 2005, 21, 53-59.

13. Korean Standards Association. Sintered Materials, Excluding Hard Metals—Determination of Transverse Rupture Strength; KS D ISO 3325; Korean Standards Association: Seoul, Korea, 2011.

14. Gonzalez, J.J.; Llorente, J.; Bram, M.; Belmonte, M.; Guillon, O. Novel Cr ${ }_{2} \mathrm{AlC}$ MAX-phase/SiC fiber composites: Synthesis, processing and tribological response. J. Eur. Ceram. Soc. 2017, 37, 467-475. [CrossRef]

15. Wang, Y.; Lei, K.; Ruan, Y.; Dong, W. Microstructure and wear resistance of c-BN/Ni-Cr-Ti composites prepared by spark plasma sintering. Int. J. Refract. Met. Hard Mater. 2016, 54, 98-103. [CrossRef]

16. Bin, C.; Ye, F.T.; Long, H.E.; Hua, T.; Li, G. Tribological properties of TiC particles reinforced Ni-based alloy composite coatings. Trans. Nonferr. Met. Soc. China 2013, 23, 1681-1688.

(C) 2018 by the authors. Licensee MDPI, Basel, Switzerland. This article is an open access article distributed under the terms and conditions of the Creative Commons Attribution (CC BY) license (http:// creativecommons.org/licenses/by/4.0/). 